\begin{abstract}
Anna Kaczmarek
Uniwersytet im. Adama Mickiewicza w Poznaniu

\section{Fluo, antracyt i rozlana benzyna, czyli o nazwach kolorów w polskiej współczesnej prasie kobiecej}

Zgodnie z założeniami definicyjnymi kolor to 'postrzegana wzrokowo właściwość przedmiotu, zależna od stopnia pochłaniania, rozpraszania lub przepuszczania promieni świetlistych; barwa' (SJP, s. 961). Ryszard Tokarski, autor publikacji Semantyka barw we wspótczesnej polszczyźnie, pisze:

[...] inspiracją dla współczesnych badań nad semantyką barw była pionierska praca lingwistów-antropologów Brenta Berlina i Paula Kaya Basic Color Terms [1969]. Autorzy na podstawie analizy leksyki kolorystycznej blisko stu języków ustalili uniwersalny inwentarz maksymalnie jedenastu podstawowych barw. [...] Dla języka polskiego można przyjąć takie nazwy, jak bialy i czarny, czerwony, żótty, zielony, niebieski, brązowy, szary, fioletowy, pomarańczowy i różowy ${ }^{1}$.

By precyzyjnie określić zasięg semantyczny leksemu kolor należy zaznaczyć, iż jest on tożsamy znaczeniowo z wyrazem barwa, lecz nie stanowi synonimu - nierzadko stosowanego zamiennie - leksemu odcień, który określa 'bardziej lub mniej intensywny stopień nasycenia jakiejś barwy; odmiana jakiegoś koloru'. Jak zauważa Krystyna Wojtczuk: ,[...] kolor jest - leksykologicznie rzecz ujmując - hiperonimem odcienia, a odcień - hiponimem koloru. Cechą definicyjną leksemu kolor jest bycie sumą odcieni"’2.

$\mathrm{Z}$ kolei w swych rozważaniach dotyczących funkcjonowania kolorów w tekstach o modzie Bożena Rejakowa wspomina, że „W antropologicznych

${ }^{1}$ R. Tokarski, Semantyka barw we wspótczesnej polszczyźnie, Lublin 2004, s. 19-21.

${ }^{2}$ K. Wojtczuk, Kreatywność językowa kobiet $w$ zakresie nazw kolorów na przykładzie tekstów współczesnej polskiej prasy kobiecej, w: Socjolingwistyczne aspekty funkcjonowania języka, Siedlce 2000, s. 113. 
dociekaniach Wojciecha Michery człowiek postrzegany jest jako istota zdolna do rozróżnienia wielkiej liczby odcieni barwnych, lecz posługująca się nimi w niewielkim tylko zakresie"3. Badaczka zwraca uwagę na to, iż

System nazewniczy barw podstawowych (które nie są semantycznie przyporządkowane innej nazwie barwy), może się kształtować różnie też w zależności od płci: uważa się, że kobiety to istoty bardziej wrażliwe na barwy, zatem dysponują też bardziej rozbudowanym systemem nazewniczym barw podstawowych (i od(cieni) $)^{4}$.

W związku ze swoistą kreatywnością, a zatem cechującą kobiety pomysłowością i oryginalnością w tworzeniu nazw i określeń kolorystycznych, zasadna wydaje się analiza pod tym właśnie względem tekstów publikowanych na łamach współczesnej polskiej prasy kobiecej. Ów rodzaj prasy reprezentowany jest przez czasopisma tworzone i redagowane przez kobiety i dla kobiet, o czym świadczą chociażby stosowane w artykułach zwroty adresatywne odnoszące się jedynie do czytelników płci żeńskiej. W niniejszym artykule odwoływać się będę do periodyków zróżnicowanych tak pod względem tematyki (moda odzieżowa, kosmetyki, kulinaria, styl życia, show-biznes itp.), jak i poziomu (nie tylko pisma określane mianem ekskluzywnych i lifestyle'owych, ale także tabloidowe). Materiał językowy wyekscerpowany został bowiem z takich czasopism jak miesięczniki „Cosmopolitan”, „Hot. Moda \& Shopping”, „InStyle” oraz dwutygodniki „Flesz”, „Grazia”, „Party” i „Show”, z okresu od stycznia 2013 roku do marca 2014 roku, a podstawę zawartej w niniejszych rozważaniach analizy stanowi ponad 300 jednostek leksykalnych. Wyodrębnione określenia kolorów zaklasyfikować można do pól tematycznych związanych z modą odzieżową, urodą oraz życiem codziennym, choć ekstensja tematyczna desygnatów, od których utworzone zostały nazwy barw, jest znacznie szersza.

W analizowanych tekstach prasowych zaobserwować można coraz niższą frekwencję nazw kolorów podstawowych, występujących bez żadnych dodatkowych określeń. Ilustrują to takie przykłady jak: „Pomarańczowa pomadka [...] najpiękniej prezentuje się na «nagiej» skórze opalonej na złoto" (P, 2013, nr 11, s. 63); „Dobra wiadomość, wiosną [...] modne będą kolorowe dodatki jak śliczna żótta kopertówka ze srebrnym wykończeniem” (G, 2013, nr 2, s. 6); „Na wieczorne wyjście zaszalej: pomaluj całą powiekę nasyconym błękitnym

${ }^{3}$ B. Rejakowa, Kulturowe aspekty języka mody, Lublin 2010, s. 92. Badaczka odwołuje się tu do artykułu Wojciecha Michery Kolory w procesie symbolizacji, opublikowanego w tomie Symbol i poznanie. W poszukiwaniu koncepcji integrujacej (red. T. Kostyrko, Warszawa 1987, s. 86-106).

${ }^{4}$ B. Rejakowa, op.cit., s. 93. 
cieniem albo przyklej sztuczne rzęsy i wytuszuj je mocno niebieska maskarą" (G, 2013, nr 4, s. 85); „Ten sezon kocha biel, i to w nowoczesnym, zimnym wydaniu” (P, 2013, nr 13, s. 52); „Braz oraz ciepły odcień koralu stanowią idealną parę" (IS, 2013, nr 8, s. 59); „Zawsze testuj czerwień w różnym świetle. I na ustach, i na grzbiecie dłoni!" (G, 2013, nr 8, s. 71). Więcej natomiast można wymienić odcieni barw podstawowych, takich jak:

1) antracyt - 'kolor szaroczarny' (WSWJ, s. 74): „Paleta występuje w dwóch wersjach kolorystycznych cieni: pudrowy róż, szarość i antracyt [...]" (G, 2013, nr 2, s. 85);

2) szylkret - jego nazwa pochodzi od określenia barwy „masy perłowej otrzymywanej z płytek okrywających pancerz kostny żółwi morskich, lekko przejrzystej, o barwie od żółtej do brunatnej” (WSWO, s. 1225): „Szylkret przeniesie ten kolor do wyższej modowej ligi” (IS, 2013, nr 8, s. 59);

3) melanż - 'mieszanina kilku odcieni najczęściej jednego koloru podstawowego': „Melanż. Zmieszana szarość. Oto nowoczesne wcielenie tweedu” (IS, 2013, nr 10, s. 36);

4) seledynowy - 'kolor bladozielony' (WSWO, s. 1135): „Czerń stroju przełamała zielonymi szpilkami i seledynowym bolerkiem” (P, 2013, nr 10, s. 96);

5) lazurowy - 'błękitny, jasnoniebieski' (WSWO, s. 732): „Mniej odważne dziewczyny mogą po prostu pomalować rzęsy fluorescencyjną lazurowa mascarą" (F, 2013, nr 12, s. 57);

6) amarantowy - 'kolor różowoczerwony $\mathrm{z}$ odcieniem fioletowym' (WSWO, s. 50): „Kup [...] torbę z amarantowymi rączkami albo buty z zielonymi wstawkami" (IS, 2013, nr 3, s. 68).

Choć można odnieść wrażenie, iż tworzenie niektórych innowacyjnych i wyszukanych określeń odcieni jest jedynie próbą uniknięcia w tekście powtórzeń nazw kolorów podstawowych (określenia te bowiem nie zawsze przystają choćby do odzwierciedlających je fotografii prasowych), to warto przyjrzeć się bliżej sposobom nominacji kolorów w prasie kobiecej.

Jak pisze Rejakowa:

[...] dociekania psychologiczne Eleonory Rosch wykazały, że podstawowe kategorie kolorów tworzą się wokół wyróżnionych prototypów - łatwych do zapamiętania i odczytania „ogniskowych” organizowanej przestrzeni barwnej. Prototypom tym przypisuje się charakter archetypów i uznaje za wspólne całemu gatunkowi ludzkiemu ${ }^{5}$.

${ }^{5}$ B. Rejakowa, op.cit., s. 92. Autorka odwołuje się do ustaleń Eleanor Rosch, profesor psychologii na University of California, na podstawie przywoływanego przez nią studium Michery (zob. przyp. 3). 
Okazuje się jednak, że przy tworzeniu nazw barw niepodstawowych prototypów może być nieskończenie wiele. Pierwszy mechanizm to układanie zarówno określeń przymiotnikowych od nazw desygnatów cechujących się daną barwą, jak i tworzenie od przymiotników derywatów rzeczownikowych (a tym samym też częste stosowanie nazw desygnatów jako nazw kolorów). Będące prototypami kolorów desygnaty zaklasyfikować można do kilku kategorii tematycznych, m.in. takich jak botanika, kulinaria oraz kamienie szlachetne i metale, dlatego też wspomniany pierwszy mechanizm kreowania określeń kolorów omówiony zostanie dla porządku osobno w każdej z nich.

Przykładami ilustrującymi botaniczne pole tematyczne są kolory pochodzące od nazw roślin: kwiatów, owoców i warzyw. Mowa tu o takich określeniach, jak:

1) trawiastozielony: ,Jeśli chcesz, by paznokcie zostały gwiazdą imprezy, pomaluj je najpierw białym lakierem, popraw trawiastozielonym, a następnie pędzelkiem do zdobienia paznokci maźnij je złotym lakierem" (C, 2013, nr 2, s. 90);

2) chabrowy: „Nasycony chabrowy kolor, do tego cytrusowe szpilki Jimmy Choo i pomarańczowe kolczyki" (F, 2013, nr 12, s. 82);

3) żonkil: „Żonkil pasuje do kolorów podstawowych: czarnego, białego i cielistego" (IS, 2013, nr 5, s. 66);

4) lawenda, wrzos, fiołek (nazwy kwiatów): „Lawenda, wrzos czy fiotki? Teraz na łące już ich nie znajdziesz. Co innego w kosmetyczce!” (F, 2013, nr 22, s. 55);

5) mięta: „Tej wiosny mięta znowu pokazała się na wybiegach [...]” (P, 2013, nr 10, s. 66);

6) pistacja: „Pistacja. Ten jasny odcień zielonego kojarzy nam się z pierwszym dniem wiosny" (IS, 2013, nr 4, s. 64).

Wśród określeń tworzonych od nazw owoców występują m.in. takie jak:

1) wisienkowy: ,Wisienkowy odcień łączy dwie strony czerwieni: zalotność z odwagą, czyli odzwierciedla prawdziwą naturę kobiety" (C, 2013, nr 3, s. 89);

2) morelowy: „Radzi też, by potem obrysować je i wypełnić konturówką w kolorze skóry, a następnie pomalować szminką w odcieniu beżoworóżowym lub morelowym" (IS, 2013, nr 2, s. 90);

3) mandarynkowy: „Dla kontrastu zestawiaj go z mandarynkowym, granatowym lub fioletowym" (IS, 2013, nr 5, s. 66);

4) brzoskwiniowy: „Przy jasnej skórze najlepsze są czerwono-pomarańczowe pomadki oraz owocowe róże, np. malinowy i brzoskwiniowy" (IS, 2013, nr 5, s. 148); 
5) bananowy: „Bananowy cień nałożony w kąciku oka i na całej górnej powiece podkreślił egzotyczną urodę gwiazdy" (P, 2013, nr 21, s. 67);

6) cytryna: „Unikaj łączenia go z turkusem - to zbyt tropikalna kombinacja. Z kolei cytryna wyciśnie z niego najwięcej orzeźwienia" (IS, 2013, nr 8, s. 58);

7) jagoda: „Jagoda świetnie wypada w połączeniu z kontrastową czernią czy szarością" (IS, 2013, nr 2, s. 48);

8) śliwka weggierka: ,Śliwka węgierka. Ten oryginalny kolor wymaga pewnej odwagi, ale warto się do niego przekonać" (G, 2013, nr 20, s. 81).

$\mathrm{Z}$ kolei nazwy warzyw inspirują do tworzenia takich określeń, jak:

1) pomidorowy: „Najważniejsze, aby kolor był żywy, jego odcień może wahać się od pomidorowego po malinowy" (IS, 2013, nr 2, s. 85);

2) baktażanowy: „Delikatne, prawie transparentne baktażanowe, [...] cienie świetnie zagrają z nasyconym kolorem szminki w malinowym odcieniu" (F, 2013, nr 16, s. 58);

3) oberżyna: „Fajnym trikiem jest również powtórzenie odcienia zbliżonego do koloru pomadki (różu, fioletu, oberżyny) na powiekach" (P, 2013, nr 21, s. 95);

4) papryka: „Najbardziej wyrafinowane będzie połączenie papryki z wytrawną zielenią, która zajmuje przeciwległe miejsca na kole barw" (IS, 2013, nr 11, s. 64).

Kolejna kategoria związana jest z polem tematycznym, w którym podstawą do tworzenia określeń barw są nazwy kamieni szlachetnych, minerałów i metali. Tę grupę leksemów Tokarski wyodrębnia jako „klasę nazw określających kamienie szlachetne, minerały, metale, związki chemiczne, częste

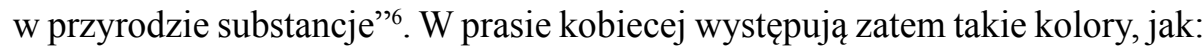

1) szmaragdowy: ,Szmaragdowy odcień tworzy piękną oprawę dla każdych oczu: zielonych, niebieskich i brązowych" (IS, 2013, nr 5, s. 146);

2) ametystowy: „Możesz wybierać różne jego odcienie: fiołkowy, ametystowy, liliowy" (IS, 2013, nr 5, s. 149);

3) szafirowy: „Szmaragdowa zieleń będzie świetnie wyglądała z szafirowymi cygaretkami" (IS, 2013, nr 9, s. 17);

4) rubinowy: „Rubinowy kolor poprawia humor” (IS, 2013, nr 2, s. 108);

5) turkus: „Popatrz na Annę Muchę: do fioletowych warg dobrała intensywny turkus na dolnej powiece!” (F, 2013, nr 15, s. 58)

6) kobalt - 'ciemnoniebieski, o głębokim odcieniu' (WSWO): „Bardziej podoba mi się więc wariant $\mathrm{z}$ intensywnym kobaltem na oku, bo dodał wokalistce wyrazistości!" (P, 2013, nr 12, s. 66).

${ }^{6}$ R. Tokarski, op.cit., s. 147. 
Ponadto odrębną grupę stanowią kolory, których nazwy, zgodnie z klasyfikacją Tokarskiego, pochodzą od „nazw obiektów, z których wytwarzano niegdyś barwniki" . Mowa tu o takich określeniach, jak:

1) karminowy - „karmin” to 'barwnik w kolorze jaskrawoczerwonym' (WSWO, s. 607): „Zainwestuj w karminowa pomadkę o lśniącym wykończeniu" (P, 2013, nr 18, s. 53);

2) indygo - "niebieski barwnik otrzymywany dawniej z liści indygowca farbierskiego' (WSWO, s. 540): „W tym sezonie modne są wszystkie odcienie - od jasnego spranego błękitu po klasyczne indygo" (G, 2013, nr 4, s. 66);

3) ultramaryna - 'farba intensywnie niebieska' (WSWO, s. 1300), definiowana przez Tokarskiego jako ,pigment mineralny o zmiennym składzie chemicznym i zabarwieniu, stosowany do wyrobu farb”. „Błękitny, chabrowy lub czysta ultramaryna! Modelki na pokazach Diora, J.P. Gaultiera, Moncler czy Fendi prezentowały różne odsłony błękitu” (G, 2013, nr 4, s. 85).

W tym miejscu warto wspomnieć o nielicznej (choć coraz częściej występującej w analizowanej prasie) grupie określeń barw, którą stanowią nazwy stosowanych w codziennym użytku substancji chemicznych. Mowa tu o takich kolorach, jak:

1) gencjanowy - ,gencjana” to "ciemnofioletowy płyn o działaniu ściągającym, wysuszającym i przeciwbakteryjnym, stosowany na skórę i śluzówki' (WSWO, s. 439): „Liczy się kolor! Ma być słodki i radosny: od limonowego po gencjanowy fiolet" (G, 2013, nr 4, s. 67);

2) benzyna: „Rada ekspertki: przy benzynie uważaj z biżuterią, bo ten lakier połyskuje i nie lubi konkurencji” (G, 2013, nr 22, s. 66); rzeczownik ten funkcjonuje także z przydawką przymiotną imiesłowową, jak w zdaniu: „Metaliczny total look «rzucił» się również na paznokcie. Modne są odcienie grafitu, asfaltu i stali (bardzo high fashion!) lub rozlanej benzyny" (P, 2013, nr 20, s. 58).

Wyekscerpowane z prasy kobiecej jednostki leksykalne zaklasyfikować można także do pola tematycznego związanego ze słownictwem kulinarnym. Wśród desygnatów stanowiących podstawę do tworzenia określeń kolorów znalazły się m.in. nazwy produktów spożywczych, w tym napojów, przypraw i alkoholi ${ }^{9}$. W tekstach występują zatem takie określenia barw, jak:

1) cukierkowy: „Pomaluj sobie paznokcie na cukierkowy czerwony kolor” (C, 2014, nr 1, s. 55);

2) śmietankowy: „Jeśli biel, to ciepła, śmietankowa...” (F, 2013, nr 19, s. 6);

${ }^{7}$ Ibidem, s. 146.

${ }^{8}$ Ibidem, s. 147.

${ }^{9}$ Ryszard Tokarski wyodrębnia grupę barw motywowanych przez nazwy potraw, napojów, przypraw i używek (R. Tokarski, op.cit., s. 148). 
3) karmelowy: „Ponieważ nie mam nóg Anny Jantar :), od razu pokochałam karmelowe kozaki" (F, 2013, nr 19, s. 55);

4) szafranowy: „I dzięki niemu podobne, ale w bardziej stonowanym szafranowym odcieniu stoją teraz w salonie Morrison” (IS, 2013, nr 5, s. 167);

5) bordowy - „bordo” to 'kolor ciemnowiśniowy'; słowo pochodzi od nazwy bordeaux oznaczającej 'wysokiej jakości francuskie wino czerwone' (WSWO, s. 171): „Bordowa szminka okazała się idealnym uzupełnieniem beżowego total looku" (F, 2013, nr 7, s. 43);

6) burgundowy - odcień głębokiej czerwieni; słowo pochodzi od nazwy „burgund” oznaczającej 'gronowe wino czerwone produkowane w Burgundii' (WSWO, s. 183): „Ciężka grzywka i burgundowy odcień włosów sprawiły, że oczy aktorki wydawały się jeszcze większe i bardziej zielone” (P, 2013, nr 16, s. 50);

7) kawa: „Dżinsy w nasyconych kolorach są też eleganckie. [...] Kawa z brzoskwiną to duet idealny!" (F, 2013, nr 12, s. 8); również nazwy jej rodzajów: „Wszystkie odcienie beżu. Cappuccino, café latte, macchiato... Czyżby manikiurzyści zainspirowali się kolorem ulubionego napoju?" (F, 2013, nr 6, s. 72);

8) miód: „Miód czy kawa? [...] Oto przewodnik GRAZII po manikiurowych trendach na nadchodzący sezon" (G, 2013, nr 22, s. 65);

9) czekolada: „Z kolei czekolada sprawdza się zarówno w pojedynkę, jak i w oryginalnych połączeniach z bordo, śliwką" [...] (G, 2013, $\mathrm{nr} 22$, s. 67);

10) cynamon: „Czekolada, kawa z mlekiem, cynamon i oczywiście miód - te kolory ogrzeją nas zimą" (G, 2013, nr 22, s. 67);

11) musztarda: „I ty dodaj trochę musztardy do swojej garderoby!” (G, 2013, nr 20, s. 63).

Innym coraz częstszym zjawiskiem w tworzeniu określeń barw jest zapożyczanie ich nazw z języków obcych, a w szczególności z języka angielskiego. Jednym z przykładów tego typu zabiegów jest odnoszący się do wielu kolorów przymiotnik fluorescencyjny funkcjonujący potocznie w znaczeniu 'jaskrawy odcień danej barwy, potocznie nazywany odblaskowym' Został on utworzony od anglicyzmu fluorescencja określającego 'samorzutne, krótkotrwałe świecenie niektórych ciał bezpośrednio po pochłonięciu promieniowania' (SZAwP, s. 79). W prasie kobiecej określenie to występuje w takich kontekstach, jak np. „Makijażyści na pokazach zamienili naturalne kolory pomadek w stylu dziewczyny z sąsiedztwa na fluorescencyjne [...]" (IS, 2013, nr 5, s. 150), a także w formie leksemu fluo, utworzonego przez skrócenie zapożyczenia, np. „Fluo odmłodzi klasyczny fason płaszcza o dobre dziesięć lat" (C, 2013, nr 11, s. 83) lub „Dodatki fluo rządzą niepodzielnie już od zeszłego lata, ale teraz prawdziwą furorę robią listonoszki w kolorze... żółtego markera!” (P, 2013, nr 11, s. 48). 
Leksem tworzy również złożenia z innymi nazwami barw, np. „Brunetki wyglądają zabójczo w kanarkowym i fluopomarańczu" (P, 2013, nr 23, s. 67). W tekstach pojawiają się też polskie odpowiedniki przymiotnika fluorescencyjny, m.in. jaskrawy, odblaskowy, neonowy, a nawet peryfraza wściekly kolor, np. „Jaskrawe kolory sygnalizują też mężczyznę, który potrzebuje w życiu sporo stymulacji [...]” (C, 2013, nr 3, s. 8); „W tym sezonie malujemy usta nie tylko odblaskowymi różami, ale też turkusami, a nawet na żółto" (G, 2013, nr 11, s. 76); „Jeśli obawiasz się zbyt mocnego efektu, wybierz neonowy odcień lżej kryjącego błyszczyku” (G, 2013, nr 12, s. 72); „Do tego możesz dodać wściekty kolor na paznokciach albo pozostać przy bardziej neutralnym" (G, 2013, nr 12, s. 72).

Wśród angielskich nazw kolorów wyróżnić można takie, których zastosowanie w tekście motywowane jest ich funkcją nominatywną. Należą tu:

1) $k$ haki - 'kolor szaro-brązowo-zielony, taki jaki zwyczajowo mają mundury wojskowe' (SZAwP, s. 111): „Hitem w mojej szafie będą cygaretki we wzory rodem z dżungli, a że jestem fanką stylu safari, to założę do nich marynarkę w kolorze khaki, przewrotnie ozdobioną kryształami” (F, 2013, nr 6, s. 55);

2) teal - 'odcień barwy niebieskiej i zielonej’: „Angielska nazwa koloru brzmi teal, czyli cyraneczka. W okresie godowym samiec tej najmniejszej kaczki w Europie ma na głowie piękny zielonomodry pasek oraz identyczną plamkę na skrzydle. Im mocniej nasycony jest odcień, tym bardziej podoba się samicom" (IS, 2013, nr 9, s. 57) ${ }^{10}$;

3) navy blue - 'ciemnoniebieski': „Kobalt, atramentowy, navy blue... Matowy, klasyczny lub z metalicznym połyskiem. Tej jesieni nosimy wszelkie odcienie granatu!"' (P, 2013, nr 20, s. 59).

Często anglicyzmy pełnią funkcję wyłącznie perswazyjną - w zamyśle autorów tekstów mają jedynie uatrakcyjnić przekaz i nadać mu swego rodzaju prestiżowy wymiar. Za takie uznać można określenia typu:

1) yellow - ‘żółty’: „Hello yellow! Nieważne, czy lubisz ciemny czy sprany dżins - kolor cytrynowy orzeźwi wszystkie odcienie niebieskiego" (S, 2013, nr 3, s. 46);

2) black and white - 'czarny i biały': „Dzięki klasycznemu duetowi black and white na pewno nie grozi nuda" (H, 2013, nr 3, s. 53);

3) blue - 'niebieski': „Jak modelki Petera Soma, zrób sobie niebiesko-zielone paznokcie. Pomaluj całą płytkę zieloną emalią, odczekaj chwilę, a następnie od połowy nałóż kolor blue. Zostaniesz trendsetterką!” (H, 2013, nr 3, s. 108);

${ }^{10}$ Warto zwrócić uwagę na dominującą w tym tekście poznawczą funkcję języka. 
4) baby blue - 'błękitny': „Na baby shower, imprezie dla przyszłej mamy, taki kolor dekoracji oznacza, że urodzi się chłopiec [...] Ale jeszcze do 1940 roku «baby blue» uznawano za odcień typowo kobiecy" (IS, 2013, nr 6, s. 67);

5) dark brown - 'ciemnobrązowy': „Konturówka do brwi w kolorze dark brown" (C, 2013, nr 10, s. 2).

Perswazyjne sfunkcjonalizowanie nazw barw (nie tylko wspomnianych anglicyzmów) ma na celu przede wszystkim nadanie im atrakcyjnego wymiaru, zachęcenie czytelniczek, by zastosować się do rad kolorystycznych i stylistycznych, wraz ze wskazaniem płynących z tego korzyści. Jak zaznacza Rejakowa, szczególnie „,W dyskursie o modzie, mającym znamiona stylu reklamowego $\mathrm{i}$ «poradniczego», barwę opisuje się ze zwróceniem uwagi na jej liczne walory 'zdobi, upiększa, odmładza, poprawia samopoczucie' itd."11. Wśród zgromadzonego materiału można przykładowo wskazać teksty zachęcające - poprzez „kolorystyczną perswazję" - do:

1) wyeksponowania seksualności: „Biel noszona od stóp do głów to jeden z hitów tego sezonu. Nie bój się jej, jest mega sexy" (C, 2013, nr 4, s. 58), „Pomarańczowe usta zestaw z kolei z wibrującym fioletem lub butelkową zielenią - tak się robi sexy look" (F, 2013, nr 14, s. 36);

2) poprawy nastroju: „Intensywny żółty kolor ma same zalety: rozświetla cerę, pasuje do każdej, nawet bardzo jasnej karnacji i poprawia nastrój. Dlatego właśnie uwielbiają go gwiazdy. Teraz czas na Ciebie!” (IS, 2013, nr 6, s. 36);

3) zwiększenia poczucia własnej wartości: „Żonkil. Jest żywiołowy i dodaje pewności siebie. Dzięki niemu będziesz miała jeszcze lepszy nastrój w ciepłe wiosenne dni" (IS, 2013, nr 5, s. 66).

W celach perswazyjnych stosowany jest również zabieg personifikacji nazw barw, widoczny w przykładach: „Konwalia, w przeciwieństwie do ciepłej, śmietankowej bieli, ma największy temperament i seksowny charakter [...]" (IS, 2013, nr 3, s. 54); „Purpura jest kolorem najbardziej introwertycznym, kryje tajemnice” (C, 2014, nr 1, s. 114); „My stawiamy na arystokratyczny pudrowy róż. Wchodzi na salony i ze znanych trendsetterek robi grzeczne dziewczynki” (C, 2013, nr 11, s. 12); „To głęboki, elegancki wręcz arystokratyczny i... wymagajacy kolor. Bordowy manikiur nie lubi towarzystwa żywych barw [...]" (P, 2013, nr 20, s. 58).

John Gage, autor publikacji Kolor i kultura oraz Kolor i znaczenie stwierdził, że ,jednym z najbardziej interesujących, choć jeszcze bardzo problematycznych powiązań między koncepcją barwy a jej odbiorem jest synestezja, mimowolny mechanizm psychologiczny, w którym powstają dwa odczucia

${ }^{11}$ B. Rejakowa, op.cit., s. 99. 
spowodowane tym samym bodźcem"12. Synestezyjne określenia kolorów w prasie kobiecej także są motywowane perswazyjnością tekstu - w analizowanych artykułach najczęściej dotyczą zmysłu smaku, np. „«Dalia» utrzymana jest w stonowanych odcieniach beżów, szarości i bieli, ale z orzeźwiającymi odcieniami żółtego i zwierzęcymi printami ” (F, 2013, nr 13, s. 39); „Nam szczególnie podobają się «smakowite» płaszcze oversize w odcieniach latte z karmelem lub świeżych jagód, ale możesz postawić też na klasyczną czerń” (P, 2013, nr 21, s. 84); „Papryka. Odcień świadczy o jej charakterze. Bywa pikantna albo stodka, podobnie jak ta w proszku” (IS, 2013, nr 10, s. 64); „Energetyczna czerwień, apetyczny pomarańcz, słoneczny żółty, soczysta zieleń, morski turkus i nasz ukochany róż. Każdy z nich jest teraz równie pożądany" (C, 2013, nr 3, s. 68).

Omówione w artykule zabiegi językowe związane z tworzeniem oraz stosowaniem nazw kolorów w tekstach publikowanych na łamach prasy kobiecej służą nie tylko funkcji nominatywnej, ale także perswazyjnej. Wśród najczęściej spotykanych sposobów kreowania nowych określeń barw wyróżnić należy zarówno wzbogacanie tekstów prasowych oryginalnymi nazwami kolorów niepodstawowych, np. „Zaprojektowana przez Papilon sukienka w kolorze cyklamenu perskiego, którą miała na sobie Agnieszka Cegielska, była jedną z najgłośniej komentowanych kreacji wieczoru" (P, 2013, nr 19, s. 4), jak i tworzenie przymiotników od rzeczowników, których desygnaty cechują się daną barwą, np. „Gdy już hojnie obmalujesz powiekę dolną i górną, sięgnij po kanarkowa żółć lub złoto z masą błyszczących drobinek i rozprowadź ją pędzelkiem" (C, 2013, nr 2, s. 88), a także tworzenie derywatów rzeczownikowych od przymiotników, np. „Żółty ma dwa odcienie: ciepły - słoneczny i chłodny - cytrynowy. Pierwszy łączymy z ciepłymi kolorami, cytrynę serwujemy schłodzoną" (S, 2013, nr 3, s. 46) ${ }^{13}$. Ponadto na uwagę zasługują również zabiegi perswazyjne, m.in. personifikacja, np. „Błękity i fiolety świetnie czuja się w towarzystwie innych cukierkowych kolorów lub bieli écru [...]" (F, 2013, nr 2, s. 12), stosowanie określeń synestezyjnych, np. „Najmodniejsze w tym sezonie spodenki muszą być bardzo krótkie i mieć soczyste kolory [...]” (P, 2013, nr 12, s. 60), czy proces zapożyczania nazw z języka angielskiego, np. Podpowiadamy, jak zrobić idealny manikiur w wersji blue" (IS, 2013, nr 4, s. 90). Trzeba zaznaczyć, że trudno wskazać różnice w tworzeniu i stosowaniu nazw kolorów w zależności od rodzaju prasy - podobne procesy i zabiegi językowe występują zarówno w tabloidach, jak i w czasopismach lifestyle'owych. Poza tym, zważywszy na wspomnianą już kreatywność kobiet zarówno

12 J. Gage, Kolor i znaczenie, Kraków 2010, s. 262.

${ }^{13}$ Leksem cytryna nie może być w tym kontekście uznany za neosemantyzm, lecz za rezultat niezależnej derywacji. 
w sposobach tworzenia nowych określeń barw, jak i wyborze należących do różnorodnych pól tematycznych desygnatów będących podstawą takich nominacji ${ }^{14}$, można przypuszczać, że scharakteryzowane tu procesy stanowią tendencję rozwojową, a liczba powstających w ich wyniku jednostek leksykalnych w tekstach prasowych, szczególnie o tematyce związanej z modą odzieżową i urodą, będzie $\mathrm{z}$ biegiem czasu wzrastać.

Stosowane skróty

Czasopisma

C - „Cosmopolitan”

$\mathrm{F}-$,Flesz”

G - „Grazia”

H - „Hot. Moda \& Shopping”

IS - „InStyle”

$\mathrm{P}-$,Party”

$\mathrm{S}-$ „Show”

Słowniki

SJP - Stownik języka polskiego, red. M. Szymczak, Warszawa 1994.

SZAwP - Stownik zapożyczeń angielskich w polszczyźnie, red. E. Mańczak-Wohlfeld, Warszawa 2010.

WSWO - Wielki stownik wyrazów obcych PWN, red. M. Bańko, Warszawa 2005.

\section{Anna Kaczmarek}

\section{Fluo, antracyt i rozlana benzyna - Colour Names in Polish Contemporary Women's Magazines}

This article discusses ways to create and use colour names in Polish contemporary women's magazines. Among these processes we can mention: enrichment of the texts in the press with original non-basic colour names, creating adjectives from nouns whose referents are characterized by a particular colour and the creation of derivatives that are nouns from adjectives. Additionally, attention is also drawn to the persuasive elements

${ }^{14} \mathrm{O}$ kreatywności autorek tekstów prasowych świadczyć może występowanie w artykułach wielu nazw kolorów, których nie notuje w swym opracowaniu Tokarski (zob. R. Tokarski, op.cit.). Mowa tu o takich określeniach, jak: baby blue, baklażanowy, bananowy, benzyna, black and white, blue, burgundowy, cukierkowy, dark brown, gencjanowy, jagoda, karmelowy, khaki, lawenda, mandarynkowy, melanż, mięta, musztarda, navy blue, oberżyna, papryka, pistacja, rozlana benzyna, szylkret, śliwka węgierka, śmietankowy, trawiastozielony, wisienkowy, yellow, żonkil. 
such as personification, the terms associated with synesthesia and the process of borrowing names from English. These colour names can be classified into thematic fields related to fashionable clothing, beauty and everyday life, although the extensions of thematic designates, from which the names of colours were created, are much wider.

KeYwORDs: names of colours, Polish contemporary women's magazines, borrowings from English

mgr Anna Kaczmarek - absolwentka studiów magisterskich na kierunku filologia polska, doktorantka w Zakładzie Frazeologii i Kultury Języka Polskiego w Instytucie Filologii Polskiej na Uniwersytecie im. Adama Mickiewicza w Poznaniu; zainteresowania naukowe: moda językowa, amerykanizacja polszczyzny, współczesna polska prasa kobieca, polski serial obyczajowy, kształtowanie się nowych profesjolektów w polszczyźnie. 